\title{
Teeth in Fire - Morphologic and Radiographic Alterations: An In Vitro Study
}

Priyanka S*, Prasad K, Raghavendra B, Avinash K and Arati P

Department of Oral Medicine and Radiology, Kavalapur, Sangli, Maharashtra, India

*Corresponding author: Priyanka S, MDS, Department of Oral Medicine and Radiology, Kavalapur, Sangli, Maharashtra, India-416306, Tel: 9822697999; E-mail: priyanka.sawant06@gmail.com

Rec date: Dec 19, 2014 Acc date: March 15, 2015, Pub date: March 23, 2015

Copyright: (C) 2015 Priyanka S, et al. This is an open-access article distributed under the terms of the Creative Commons Attribution License, which permits unrestricted use, distribution, and reproduction in any medium, provided the original author and source are credited.

\begin{abstract}
Teeth are the components of the body that often survive severe fires because of their high resistant composition and also because they are protected by the soft and hard tissues of the face. The damage caused by heat can make medico legal identification of human remains difficult in mass disasters associated with fire. The morphologic and radiographic evaluation of dental remains represents a significant aspect in the forensic identification process, particularly after an exposure to fire.
\end{abstract}

Aim: The aim of this "in vitro" study was to evaluate the morphologic and radiographic features of teeth after exposure to an experimental range of high temperatures.

Methods: A total of 60 extracted permanent teeth were exposed to heat in an Unident digital muffle furnace at five different temperatures $\left(100,300,500,700\right.$ and $\left.1000^{\circ} \mathrm{C}\right)$. Before and after each exposure, periapical radiographs of all the teeth were taken. The morphologic and radiographic appearances of all the teeth before and after exposure to heat were evaluated and the differences were recorded.

Results: The general progression of the colour change from lower temperature to higher was typical light yellow colour, yellowish brown, greyish brown, bluish grey and neutral white. In radiographic evaluation we observed intact teeth at $100^{\circ} \mathrm{C}$, a progressive formation of fissures at $300^{\circ} \mathrm{C}$ and fractures between enamel and dentin at $700^{\circ} \mathrm{C}$, large fractures spreading through the dentin and crown crushing at $1000^{\circ} \mathrm{C}$. Longitudinal and transverse cracks of root were observed at $1000^{\circ} \mathrm{C}$.

Conclusion: Morphologic and radiographic alterations caused by incineration may provide useful information about the temperature and duration of exposure to fire. It can also aid in understanding the circumstances surrounding the fire.

Keywords: Forensic science; Forensic odontology; Identification; Radiographs; High temperatures

\section{Introduction}

A precise understanding of morphologic and radiographic changes in teeth subjected to high temperatures is of great importance in forensic medicine. The type and severity of structural damage provide valuable clues in fire and criminal investigations, especially when only dental evidence remains [1]. Radiological examination provides important information in the dental practice and it is considered definitive evidence in court or identification cases [2]. Teeth exposed to high temperatures have the potential to not only aid in identification, but also in understanding the circumstances surrounding the fire [3].

Teeth are the components of the body that often survive severe fires because of their high resistant composition and also because they are protected by the soft and hard tissues of the face and other elements [4-8]. Literature review shows that, macroscopic colour variations of unrestored teeth could be related to the temperature rise and time of application. It was believed that the temperature levels and the combustion time were inversely proportional to the rate of colour changes [5].
All of the currently available literature on incinerated teeth has been conducted for macroscopic and microscopic changes. The apparent lack of data on heat related morphologic and radiographic changes in teeth subjected to high temperature thus necessitates this type of experimental study.

The aim of this study was to evaluate the gross morphological changes in teeth subjected to specific temperatures $(100,300,500,700$ and $1000^{\circ} \mathrm{C}$ ) for specific duration. The study also aims to evaluate and compare the radiographic features of teeth, before and after exposure to high temperatures.

\section{Materials and Methods}

A total of 60 permanent teeth were studied; 20 anteriors, 20 premolars and 20 molars. The control samples were kept separately and thus not exposed to the experimental temperatures. All the teeth analyzed were extracted for orthodontic and periodontal purpose, without any cavities, restorations, endodontic treatments and congenital malformations. Following extraction each tooth was rinsed with saline water to remove blood deposits and salivary coating. The teeth were then stored in $10 \%$ formalin. Formalin ( $10 \%$ concentration) was used as the storage medium for the teeth because it is an effective 
Page 2 of 4

disinfecting and sterilizing agent for extracted teeth without altering their hardness [9].

All the teeth were equally divided into 5 groups according to temperatures of exposure, $100^{\circ} \mathrm{C}, 300^{\circ} \mathrm{C}, 500^{\circ} \mathrm{C}, 700^{\circ} \mathrm{C}$ and $1000^{\circ} \mathrm{C}$ (Figure 1). Then, periapical radiographs of all the samples were recorded before exposure to high temperatures using the following procedure: KODAK Dental Intraoral E-Speed Film, with Bio-Medicare 1070D Machine at $65 \mathrm{Kvp}, 10 \mathrm{~mA}$ and exposure time of 0.5 seconds with the long cone paralleling technique. These X-ray films were processed with KODAK Dental X-Ray Developer and Fixer.

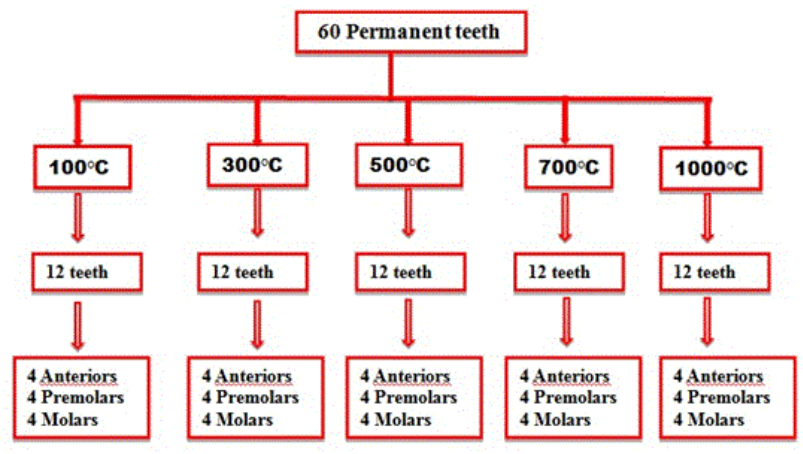

Figure 1: Teeth were equally divided into 5 groups according to temperatures of exposure, $100^{\circ} \mathrm{C}, 300^{\circ} \mathrm{C}, 500^{\circ} \mathrm{C}, 700^{\circ} \mathrm{C}$ and $1000^{\circ} \mathrm{C}$.

The 5 groups of samples were exposed to high temperatures using an Unident digital muffle furnace at experimental temperatures starting at $100^{\circ} \mathrm{C}$ up to a maximum of $1000^{\circ} \mathrm{C}$. The teeth were placed in a porcelain stub inside the furnace and exposed to high experimental temperatures. Once placed in the furnace, the teeth were exposed to high temperature for a period of 30 minutes; the teeth were then removed and allowed to cool to room temperature. After each heat exposure the teeth were radiographed in the same way as described previously. The resulting radiographic and morphologic differences concerning the samples before and after exposure to high temperatures were recorded and listed. The study was approved by ethical board of institute.

\section{Results}

All the teeth exposed to different experimental temperatures showed different morphologic and radiographic appearances. All the teeth were intact with pale to light yellow colour at $100^{\circ} \mathrm{C}$. The crown retained its surface. At $100^{\circ} \mathrm{C}$ no appreciable changes were noticed radiographically.

At $300^{\circ} \mathrm{C}$ teeth showed light grey with dark grey patches on crown and yellowish brown coloured roots. All the teeth were intact but radiographically fissures observed between enamel and dentin.

After exposure to $500^{\circ} \mathrm{C}$, all the teeth showed crown with light to dark bluish grey colour. The colour of roots turned to greyish brown colour. At $500^{\circ} \mathrm{C}$ and above loss of surface luster was noted. Many teeth were disintegrated into fragments at $500^{\circ} \mathrm{C}$. The radiographic evaluation pointed out fractures between enamel, dentin and extending within dentin.

The colour of all the teeth were turned to light to dark bluish grey colour at $700^{\circ} \mathrm{C}$. All the teeth specimens were disintegrated into small fragments. Radiographically presence of many fractures between enamel and dentin were noted.

At $1000^{\circ} \mathrm{C}$ teeth showed neutral white colour with light greenish grey patches. Teeth showed presence of large fractures spreading through the dentin and crown crushing were observed radiographically (Figure 2). The results of morphologic and radiographic evaluation are outlined in Table 1, according to temperatures and exposure time.

\begin{tabular}{|c|c|c|c|c|c|}
\hline Sr. No & $\begin{array}{l}\text { Temperature in } \\
\text { degrees centigrade }\end{array}$ & $\begin{array}{l}\text { Duration } \\
\text { minutes }\end{array}$ & Sample Size & Morphologic changes & Radiographic Changes \\
\hline 1 & 100 & 30 & 12 & $\begin{array}{l}\text { Pale to light yellow } \\
\text { retained surface luster }\end{array}$ & No appreciable changes \\
\hline 2 & 300 & 30 & 12 & $\begin{array}{l}\text { Light gray with dark gray patches } \\
\text { Roots - Yellowish brown }\end{array}$ & Fissures between enamel and dentin \\
\hline 3 & 500 & 30 & 12 & $\begin{array}{l}\text { Enamel - Light to Dark bluish gray Patches } \\
\text { Roots - Grayish brown } \\
\text { Loss of surface luster }\end{array}$ & $\begin{array}{l}\text { Fractures between enamel/dentin and } \\
\text { within dentin }\end{array}$ \\
\hline 4 & 700 & 30 & 12 & $\begin{array}{l}\text { Light bluish gray to Dark bluish gray } \\
\text { Disintegration into small fragments }\end{array}$ & $\begin{array}{l}\text { Fractures between enamel/dentin and } \\
\text { within dentin }\end{array}$ \\
\hline 5 & 1000 & 30 & 12 & $\begin{array}{l}\text { Neutral white with Light bluish gray } \\
\text { And Light greenish gray patches }\end{array}$ & $\begin{array}{l}\text { Large fractures spreading through } \\
\text { dentine and crown crushing. }\end{array}$ \\
\hline
\end{tabular}

Table 1: Morphologic and radiographic changes observed in teeth exposed to high temperatures for 30 minutes. 


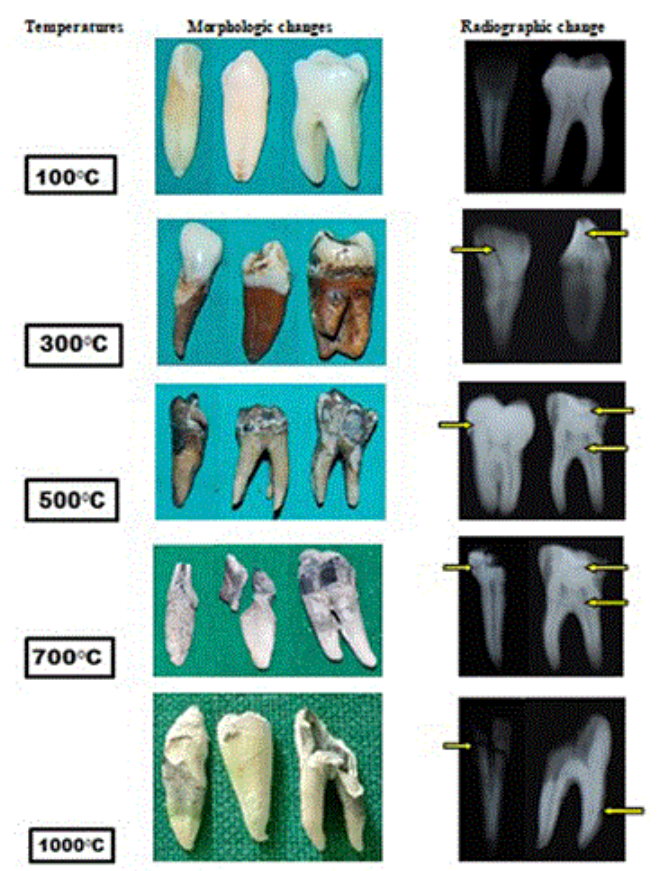

Figure 2: Large fractures spreading through the dentin and crown crushing were observed radiographically.

\section{Discussion}

In forensic odontology a great deal of effort goes into identifying the victim. One method of identification in forensic odontology is to examine the burned bodies and their fine traces, as well as to examine the resistance of teeth to high temperature [7]. Dental identification is one of the most reliable and frequently applied methods of identification, and forensic odontology is a speciality in itself. The establishment of forensic odontology is a unique discipline that has been attributed to Dr. Oscar Amoedo (Father of Forensic Odontology) who identified the victims of fire accident in Paris, France in 1897 [10].

In our study we have observed the morphologic and radiographic changes to the teeth exposed to high temperatures. All of the research analyzing burnt dental remains currently available in the literature has been conducted on macroscopic and microscopic changes in unrestored and restored teeth. The apparent lack of data on radiographic alterations along with morphologic changes in teeth at various high temperatures necessitates research in this area.

It was found that the colour of the teeth was the most important indicator of their relative fragility. This confirms previous research which suggests that blackened teeth are less fragile in comparison with remains that are grey or white in colour [4]. In our research, the teeth mainly showed changes fromlight yellow colour, yellowish brown, greyish brown passing through bluish grey, which turned completely neutral white at $1000^{\circ} \mathrm{C}$. This is directly related to the level of carbonization and incineration of teeth. All of these changes were also described by Merlati et al., Gunther and Schdmidt-quoted by Rotzscher., Muller et al., Merlati, Danesino et al., and Bagdey et al. $[6-8,11,12]$. Thus, small fragments of teeth can be identified from the burn remains and a reliable estimation of the temperature of exposure can be made. It was found that at lower temperatures the teeth fragmented into large particles and at higher temperature teeth disintegrated into numerous smaller particles. A similar observation has been reported by Karkhanis [3].

From the results of our study, it is observed that teeth were not strongly affected by the temperature exposure till $100^{\circ} \mathrm{C}$. Above $300^{\circ} \mathrm{C}$ the radiographic changes observed were a progressive formation of fissures between enamel and dentin, fractures between enamel-dentin and within dentin, large fractures spreading through the dentin and crown crushing at $1000^{\circ} \mathrm{C}$. The radiographic properties of the roots were available for the analysis till the $1000^{\circ} \mathrm{C}$. A similar observation has been reported by Savio et al [2].

The colour of bone fragments affected by high temperatures is a function of oxygen availability, duration and temperature. Colour changes in teeth are similar to those documented in bone [13]. At initial temperatures the organic components begin to carbonize then at higher temperatures as carbonation is completed and the carbonates begin to disappear resulting in black or dark grey colour depending the duration of the heat exposure. At high temperatures of $800^{\circ} \mathrm{C}$ or more, bone becomes "calcined" and the colour changes to blue-grey or white [14]. A similar type of colour changes can be observed in teeth at different temperatures as seen in our study.

Our study did not take into account possible variables present in an in-vivo condition such as the protection from soft and hard tissues surrounding dental elements and dental appliances present in mouth. Such structures protect the teeth from direct exposure to fire.

\section{Conclusion}

Morphologic and radiographic alterations caused by fire may provide useful information about the temperature and duration of exposure to fire. It can also aid in understanding the circumstances surrounding the fire. This study can help the forensic investigators in preplanning the systematic approach toward the preservation of incinerated dentition, as it could prove to be the best evidence for identification of those who are extensively burned.

\section{References}

1. Myers SL, Williams JM, Hodges JS (1999) Effects of extreme heat on teeth with implications for histologic processing. J Forensic Sci 44:805-809.

2. Savio C, Merlati G, Danesino P, Fassina G, Menghini P (2006) Radiographic evaluation of teeth subjected to high temperatures: Experimental study to aid identification processes. Forensic SciInt 158: 108-116.

3. Karkhanis S, Ball J, Franklin D (2009) Macroscopic and microscopic changes in incinerated deciduous teeth. J Forensic Odontostomatol 27: 22.

4. Delattre VF (2000) Burned beyond recognition: systematic approach to the dental identification of charred human remains. J Forensic Sci. 45: 589-596.

5. Moreno S, Merlati G, Marin L, Savio C, Moreno F (2009) Effects of high temperatures on different dental restorative systems: Experimental study to aid identification processes. J Forensic Dent Sci 1: 17-123.

6. Merlati G, Savio C, Danesino P, Fassina G, Menghini P (2004) Further study of restored and unrestored teeth subjected to high temperatures. J Forensic Odontostomatol 22: 17-24.

7. Rotzscher K, Grundmann C, benthaus S (2004) The effects of high temperatures on human teeth and dentures. Int Poster J Dent Oral Med 6: 213 . 
Citation: $\quad$ Priyanka S, Prasad K, Raghavendra B, Avinash K, Arati P (2015) Teeth in Fire - Morphologic and Radiographic Alterations: An In Vitro Study. J Forensic Res 6: 1000277. doi:10.4172/2157-7145.1000277

Page 4 of 4

8. Mazza A, Merlati G, Savio C, Fassina G, Menghini P (2005) Observations on dental structures when placed in contact with acids: Experimental studies to aid identification processes. J Forensic Sci 50: 406-410.

9. Kumar M, Sequeira PS, Peter S, Bhat GK (2005) Sterilisation of extracted human teeth for educational use. Indian J Med Microbiol 23: 256-258.

10. Patidar KA, Parwani R, Wanjari S (2010) Effects of high temperature on different restorations in forensic identification: Dental samples and mandible. J Forensic Dent Sci 2: 3743.

11. Muller M, Berytrand MF, Quatrehomme G, Bolla M, Rocca JP (1998) Macroscopic and microscopic aspects of incinerated teeth. J Forensic Odontostomatol 16: 1-7.
12. Shubhangi PB, Rohit BM, Alka MD, Samantha T, Ashish B (2014) Effect of various temperatures on restored and unrestored teeth: A forensic study. J Forensic Dent Sci 6: 62-66.

13. Ubelaker DH (2009) The forensic evaluation of burned skeletal remains: A synthesis. Forensic Sci Int 183: 15.

14. Phillip LW, Kevin WPM, Rebecca R (2014) Time, temperature, and oxygen availability: an experimental study of the effects of environmental conditions on the colour and organic content of cremated bone. In Press in: Burned Bone. C.W. Schmidt (ed.) Elsevier Press. 